\title{
COMMENT
}

\section{Inaccurate bivalve clearance rate measurements: a reply}

\author{
Hans Ulrik Riisgård*
}

Research Centre for Aquatic Biology (Institute of Biology, Southern Danish University), Hindsholmvej 11, 5300 Kerteminde, Denmark

A precondition for making credible estimates of 'scope for growth' and for studying possible physiological regulation in bivalves is the ability to make accurate and reproducible measurements. This was the main message in my 'stony road' review (Riisgård 2001a) and this was also emphasised in my recent reply to a comment by Cranford (2001) (Riisgård 2001b). Physiological regulation of filtration in filterfeeding bivalves has recently been discussed in a follow-up paper (Riisgård 2001c) and will not be further treated in the present reply to Widdows (2001) although the subject is relevant in regard to Widdows' assumption that suspension feeders are generally not performing at their maximum clearance rate due to the influence of collecting site of animals.

In his comment Widdows (2001) points out certain inaccuracies concerning the cited literature, but the example given is not quite valid: using the flowthrough chamber method, cf. Eq. (1) in Riisgård (2001a), Smaal \& Twisk (1997) employed a constant

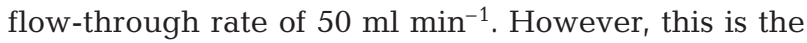
flow-through rate suggested by Widdows (1985) when using the steady-state method, cf. Eq. (6) in Riisgård (2001a) which is the 'corrected formula' given by Hildreth \& Crips (1976). Presumably, Small \& Twisk (1997) assumed that they followed Widdows' recommendation, which, however, for the method used should have been 'a flow rate of at least $150 \mathrm{ml} \mathrm{min}^{-1}$ '.

It is true as stated by Widdows (1985) that, besides the filtration rate of the mussel, 'minimum flow rate required will depend on the size and geometry of the experimental chamber' and that 'clarification of this potential artefact should ... precede any study of clearance rate using flow-through techniques'. This reasonable statement is in agreement with my earlier examination of the flow-through chamber method (Riisgård 1977) where it is concluded that the 'clearance rates are representative of the filtration rates using rates above a critical level and troughs of suitable geometry', see also Fig. 1. But regrettably, no proper exami-

*E-mail: hur@biology.sdu.dk nation of the necessary prerequisites for using the method has hitherto been made by any group. Presumably due to recognised problems with re-circulation, the flow-through rate used has been rising over the years (but no efforts for improving chamber size and shape can be noticed although the chamber

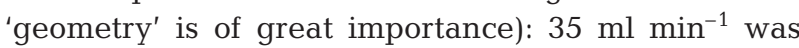

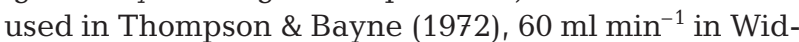

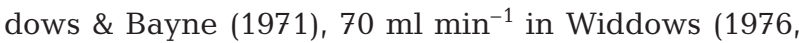
1978), 60 to $90 \mathrm{ml} \mathrm{min}^{-1}$ in Bayne et al. (1976), 100 to

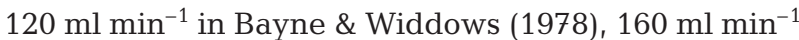

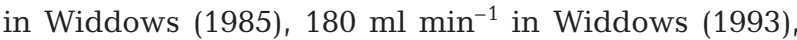
and more recently, the flow-through rate was 'adjusted so that the outflow particle concentration is not more than $30 \%$ below the inflow concentration' (Smaal \& Widdows 1994). But no systematic study appears to have been published to show how filtration rate is affected by shape and size ('geometry') of the chamber, as well as by the flow-through rate (cf. Fig. 1).

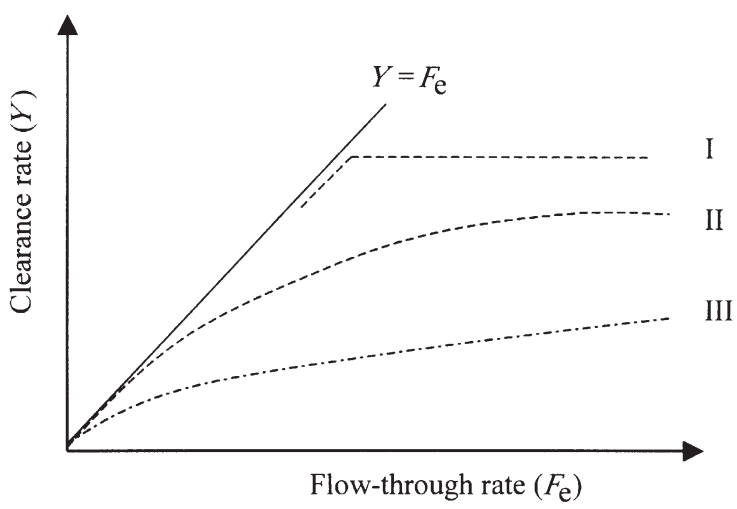

Fig. 1. One way of checking the 'geometry' of a flow-through chamber is to determine to what degree the clearance rate values $(Y)$ for smaller flow-through rates $\left(F_{\mathrm{e}}\right)$ tend to deviate from the line given by $Y=F_{\mathrm{e}}$. Clearance rates that approach this line indicate that the geometry of the chamber is about optimal. Above a certain critical flow-through rate the clearance rate values deflect from the line $Y=F_{\mathrm{e}}$ and tend to form a plateau where the clearance rates are representative of the true filtration rate of the bivalve. The hypothetical curves show: I: good geometry of chamber; II: poor geometry; III: very poor geometry indicating that the chamber is unfit for use 
It is well known that the filtration rate $(F)$ as a function of body dry weight $(W)$ can be described by the allometric equation $F=\mathrm{a} W^{\mathrm{b}}$, where the exponent $\mathrm{b}$ is close to $2 / 3=0.67$ (actual values for different bivalve species vary between 0.62 and 0.75 , see Table 1 in Riisgård 2001a). The generally low filtration rates (low a-values) and low b-exponents reported from flowthrough chamber studies suggest that the prerequisites have not been fulfilled, especially not for the larger mussels. It is important to realize that a recom-

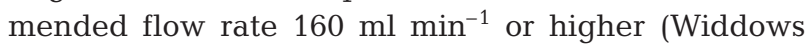
1985) may not necessarily be valid for a chamber with bad 'geometry', re-circulation and bypass flow, cf. appendix by Poul S. Larsen in Riisgård (2001a). Erroneous use of the flow-through chamber method has resulted in many incorrect values of filtration rates, but the reviewed literature showed that most other laboratory methods agree well (Riisgård 2001a), irrespective of the collection site of animals investigated. The majority of the world literature on bivalve feeding rates should not be dismissed, but a great part of the literature dealing with flow-through chamber techniques used in studies on 'scope for growth' in bivalves clearly needs to be critically examined and reinterpreted.

Filtration rates as a function of size in a number of bivalve species, measured by means of different methods (suction, photoaquarium, clearance, replacement, and thermistor methods) by different workers under optimal laboratory conditions have been shown in terms of a-values and b-exponents of the allometric equation in Table 1 in Riisgård (2001a). Estimates obtained by the various methods are similar, and they are apparently not biased by either methodological flaws or the collecting sites of animals investigated. Intentionally, a-values and b-exponents obtained by means of the flow-through chamber method were excluded from the table because such results were often consistently low, hence believed to be unreliable due to the prerequisites not being satisfied for using the method (good 'geometry' of chamber, flow rate above a certain critical level, 100\% retention of particles). A few examples of low a-values and low b-exponents may serve as examples: Thompson \& Bayne (1974) found that the relationship is a power function for specimens less than $1 \mathrm{~g}$ dry flesh wt, with a weight exponent of $b=0.38$. Bayne et al. (1976) found that the relationship between filtration rate $\left(F, \mathrm{l} \mathrm{h}^{-1}\right)$ and body size ( $W, g$ dry flesh wt) in Mytilus californianus could be described by the equation $F=1.61 W^{0.458}$ in fed and $F=1.02 W^{0.416}$ in starved Mytilus edulis. Widdows (1978) found that the relationship could be described by the equation: $F=2.65 W^{0.38}$. These b-exponents are considerably lower than the expected exponent of $\mathrm{b}=$ 0.67 , and also the a-values are (very) low compared to values found by other workers using different methods (see Riisgård 2001a, Table 1 therein). In the case of Mytilus spp. the following a-values have been determined under optimal conditions: $7.45 \mathrm{l} \mathrm{h}^{-1}$ (suction method, Møhlenberg \& Riisgård 1979), $7.37 \quad \mathrm{l} \mathrm{h}^{-1}$ (photoaquarium method, Riisgård \& Møhlenberg 1979), $7.9 \mathrm{l} \mathrm{h}^{-1}$ (thermistor method, Meyhöfer 1985). Because the a-value represents the filtration rate of a $1 \mathrm{~g}$ dry body wt mussel the above values may be directly compared to more recent filtration rates obtained on $M$. edulis by Widdows et al. (1995) using the flow-through chamber method. In the case of 'clean' Shetland mussels the specific filtration rate was found to be $6.5 \mathrm{l} \mathrm{g}^{-1}$ $\mathrm{h}^{-1}$ which is roughly 2.5 times higher than reported in several earlier papers by Widdows and collaboratorsbut so far, no plausible explanation for this striking difference has been given.

A key argument put forward by Widdows (2001) is that mussels collected from the majority of coastal and estuarine sites in the UK do not filter at their maximum potential 'due to the presence of pollutants in their body tissues'. Thus, the maximal feeding rates recorded by Møhlenberg \& Riisgård (1979) 'probably reflect the origin of the animals, which were collected from the northern part of the Øresund in Denmark' . At this collecting site "the "optimal" environmental conditions ... are probably atypical and relatively few animals living in the coastal waters of densely populated and industrial Europe are feeding and growing under "optimal" conditions'. If this far-reaching and worrying statement were true the filtration rates of the different bivalve species listed in Table 1 in Riisgård (2001a) would presumably show much more variation because the collecting sites of the bivalves are very different: e.g. Øresund and Wadden Sea (Denmark), False Bay (South Africa); Georgia Bight and San Juan Island (USA). The conclusion is clear: it is of utmost importance for future research into long-term environmental effects that the accuracy of any method for filtration rate be ascertained, in particular the flowthrough chamber method.

Acknowledgements. Thanks are due to Prof. Poul S. Larsen, Fluid Mechanics Section, Technical University of Denmark, for constructive criticism.

\section{LITERATURE CITED}

Bayne BL, Widdows J (1978) The physiological ecology of two populations of Mytilus edulis L. Oecologia 37:137-162

Bayne BL, Bayne CJ, Carefoot, TC, Thompson RJ (1976) The physiological ecology of Mytilus californianus Conrad. 1. Metabolism and energy balance. Oecologia 22:211-228

Cranford PJ (2001) Evaluating the 'reliability' of filtration rate measurements in bivalves. Mar Ecol Prog Ser 215: 303-305

Hildreth DI, Crisp DJ (1976) A corrected formula for calculation of filtration rate of bivalve molluscs in an experi- 
mental flowing system. J Mar Biol Assoc UK 56:111-120

Meyhöfer E (1985) Comparative pumping rates in suspension-feeding bivalves. Mar Biol 85:137-142

Møhlenberg F, Riisgård HU (1979) Filtration rate, using a new indirect technique, in thirteen species of suspension feeding bivalves. Mar Biol 54:143-148

Riisgård HU (1977) On measurements of the filtration rates of suspension feeding bivalves in a flow system. Ophelia 16: 167-173

Riisgård HU (2001a) On measurement of filtration rate in bivalves - the stony road to reliable data, review and interpretation. Mar Ecol Prog Ser 211:275-291

Riisgård HU (2001b) The stony road to reliable filtration rate measurements in bivalves: a reply. Mar Ecol Prog Ser 215: 307-310

Riisgård HU (2001c) Physiological regulation versus autonomous filtration in filter-feeding bivalves: starting points for progress. Ophelia 54:193-209

Riisgård HU, Møhlenberg F (1979) An improved automatic recording apparatus for determining the filtration rate of Mytilus edulis as a function of size and algal concentration. Mar Biol 52:61-67

Smaal AC, Twisk F (1997) Filtration and absorption of Phaeocystis cf. globosa by the mussel Mytilus edulis. J Exp Mar Biol Ecol 209:33-46

Smaal AC, Widdows J (1994) The scope for growth of bivalves as an integrated response parameter in biological monitoring. In: Kramer KJM (ed) Biomonitoring of coastal waters and estuaries. CRC Press Inc., Boca Raton, p 247-267 Thompson RJ, Bayne BL (1972) Active metabolism associated with feeding in the mussel Mytilus edulis L. J Exp Mar Biol Ecol 9:111-124

Thompson RJ, Bayne BL (1974) Some relationships between growth, metabolism and food in the mussel Mytilus edulis. Mar Biol 27:317-326

Widdows J (1976) Physiological adaptation of Mytilus edulis to cyclic temperatures. J Comp Physiol 105:115-128

Widdows J (1978) Combined effects of body size, food concentration and season on the physiology of Mytilus edulis. J Mar Biol Assoc UK 58:109-124

Widdows J (1985) Physiological procedures. In: Bayne BL, Brown DA, Burns K, Dixon DR and 6 others (eds) The effects of stress and pollution on marine animals. Praeger, New York, p 161-178

Widdows J (1993) Marine and estuarine invertebrate toxicity tests. In: Calow P (ed) Handbook of ecotoxicology, Vol. 1, Chap 9. Blackwell Scientific, Oxford, p 145-166

Widdows J (2001) Bivalve clearance rates: inaccurate measurements or inaccurate reviews and misrepresentation? Mar Ecol Prog Ser 221:303-305

Widdows J, Bayne BL (1971) Temperature acclimation of Mytilus edulis with reference to its energy budget. J Mar Biol Assoc UK 51:827-843

Widdows J, Donkin P, Brinsley MD, Evans SV and 4 others (1995) Scope for growth and contaminant levels in North Sea mussels Mytilus edulis. Mar Ecol Prog Ser 127:131-148 